a Universidade Estadual do Norte Fluminense Darcy Ribeiro, Centro de Ciência e Tecnologia, Programa de Pós-Graduação em Ciências Naturais, Laboratório de Ciências Químicas, Avenida Alberto Lamego 2000, CEP 28013-602, Campos dos GoytacazesRJ, Brasil.

'Instituto Federal Fluminense, campus Campos-centro, Rua Dr. Siqueira 273, Parque Dom Bosco, CEP 28030-130, Campos dos Goytacazes-RJ, Brasil.

Instituto Federal Fluminense, campus Itaperuna, Rodovia BR-356 Km $3 \mathrm{~s} / \mathrm{n}$, Cidade Nova, CEP 28300-000, Itaperuna-RJ, Brasil. dUniversidade Federal Rural do Rio de Janeiro, Instituto de Química, Departamento de Química Orgânica, Br 465 Km 7, CEP 23897-035 Seropédica-RJ, Brasil.

*E-mail: curcino@ uenf.br

Recebido: 22 de Março de 2021

Aceito: 22 de Março de 2021

Publicado online: 7 de Julho de 2021

\section{Isolation and Identification of Prenylated Coumarins from the Species Flindersia brayleyana F.Muell (Rutaceae)}

\author{
Isolamento e Identificação de Cumarinas Preniladas da Espécie Flindersia \\ brayleyana F. Muell (Rutaceae)
}

Lara P. S. Nascimento, ${ }^{a}$ Michel de S. Passos, ${ }^{a}$ Thalya S. R. Nogueira, ${ }^{a}$ Milena G. C. Vieira, ${ }^{b}$ Antônio Sérgio N. Moreira, ${ }^{c}$ Raimundo Braz-Filho, ${ }^{a, d}$ Ivo J. C. Vieira ${ }^{a, *}$ (D)

The Rutaceae family is known for its representative genera in the society in which we live and also for being one of the most chemically versatile plant families. The genus Flindersia is part of this family and produces alkaloids and coumarins as the main secondary metabolites. Coumarins stand out for their many important biological activities and are identified as the predominant class in the species Flindersia brayleyana. Therefore, the main objective was the isolation and structural characterization of the secondary metabolites of Flindersia brayleyana. The structures of the isolated compounds were elucidated through the analysis of $1 \mathrm{D}$ and $2 \mathrm{D}$ spectra of ${ }^{1} \mathrm{H} \mathrm{NMR}$ and ${ }^{13} \mathrm{C} \mathrm{NMR}$ and GC/MS, involving comparison with data from the literature. The coumarins Seselin (1), Braylin (2), Cedrelopsin (3), cis-6-methoxykellactone (4), 6-methoxylomatin (5), and Brayleyanin (6) were identified.

Keywords: Rutaceae; Flindersia brayleyana; prenylated coumarins.

\section{Introduction}

Even before the advent of extensive studies, plant species were widely used by society to relieve pain and cure disease. Today it is known that plant species contain compounds of a chemical nature, called secondary metabolites, which are involved in the defense mechanism of plants and are the object of studies, in isolation or in extracts, to research their mechanism of action, and thus, to verify their activity in the organism of living beings. ${ }^{1,2}$

Therefore, the current work aimed to study the species Flindersia brayleyana (Rutaceae). The family Rutaceae, considered pantropical and with approximately 150 genera, is found abundantly in the tropics and subtropics, being one of the most chemically versatile plant families and known for its leaves, which have translucent spots through which essential oil is secreted from the glands, emitting strong aromas..$^{3-5}$

The genus Flindersia, with 17 species, is differentiated from others of the Rutaceae family through fruit analysis: Flindersia has five carpels and the other genera only four. ${ }^{6,7}$

The bibliographic survey conducted with the genus Flindersia revealed alkaloids and coumarins as principal secondary metabolites in fixed components and monoterpenes and sesquiterpenes in essential oils, with coumarins being the dominant class in the species Flindersia brayleyana. , $^{6,9}$

Coumarins stand out for their medicinal potential and their very versatile bioactivities, represented by compounds that present anti-inflammatory, analgesic, antioxidant, anticoagulant, anti-HIV, and antimicrobial effects, among others. ${ }^{10-12}$ This is due to the large number of structures present in this class of secondary metabolites. In addition, the majority of the recently identified pyranocoumarins are reported to belong to the Rutaceae family. ${ }^{13}$ Given this, the objective of the current work is to isolate and identify secondary metabolites of the species Flindersia brayleyana.

\section{Experimental}

\subsection{General experimental procedures}

The following chromatographic techniques were applied: Column Chromatography (CC) was performed on silica gel 60 (0.063-0.200 mm, Merck); Preparative Thin Layer Chromatography 
(PTLC) was performed on silica gel $60 \mathrm{PF}_{254}$ containing gypsum (Merck); and Thin Layer Chromatography (TLC) was performed on aluminum chromatography sheets with silica gel $60 \mathrm{~F}_{254}$ (Merck). The following were used as mobile phase solvents, purchased from Synth (São Paulo, Brazil): Methanol $\left(\mathrm{CH}_{3} \mathrm{OH}-99.8 \%\right)$, dichloromethane $\left(\mathrm{CH}_{2} \mathrm{Cl}_{2}\right.$ $99.5 \%), n$-hexane (98.5\%), and acetone (99.5\%). For the identification and elucidation of substances: 1D and 2D NMR experiments were performed on a $500 \mathrm{MHz}$ Bruker Ascend $500 \mathrm{NMR}$ spectrometer operating at $500 \mathrm{MHz}$ for ${ }^{1} \mathrm{H}$ NMR and $125 \mathrm{MHz}$ for ${ }^{13} \mathrm{C}$ NMR. Deuterated chloroform $\left(\mathrm{CDCl}_{3}\right)$, tetradeuterated methanol $\left(\mathrm{CD}_{3} \mathrm{OD}\right)$, and deuterated acetone $\left(\left(\mathrm{CD}_{3}\right)_{2} \mathrm{CO}\right)$, containing TMS (tetramethylsilane) as an internal standard, were used. GC/EIMS were obtained on a spectrometer GC-MS 5975C Inert XL EI/CI/MS Agilent Technologies, coupled to a gas chromatography system $7890 \mathrm{~A}$, with the use of the positive ion mode of analysis.

\subsection{Collection of material}

The stem and wood bark of the species Flindersia brayleyana, were collected in November 2018 at Linhares, ES, Brazil (latitude 1906'54" S, longitude 39 $56^{\prime} 20^{\prime \prime}$ O). The voucher specimen $\left(n^{\circ} 8817\right)$ was deposited in the herbarium of the Universidade Federal de Viçosa (UFV).

\subsection{Extraction and isolation}

The Flindersia brayleyana stem and wood bark ( 2 and 2.3 $\mathrm{Kg}$, respectively) were dried and powdered, and the extraction was performed with methanol. Both of the methanolic extracts were partitioned with $\mathrm{CH}_{2} \mathrm{Cl}_{2}, \mathrm{BuOH}$, EtOAc, and $\mathrm{H}_{2} \mathrm{O}$. The dichloromethane partition of the stem $(47.3 \mathrm{~g})$ was fractionated by silica gel $\mathrm{CC}$, with a polar gradient of $\mathrm{CH}_{2} \mathrm{Cl}_{2}: \mathrm{MeOH}$, obtaining 7 fractions (FCD1-FCD7). FCD1 $(1.4 \mathrm{~g})$ was chromatographed, with a polar gradient of $\mathrm{CH}_{2} \mathrm{Cl}_{2}: \mathrm{MeOH}$, generating 7 fractions (FCD1.1 - FCD1.7). PTLC was performed with fraction FCD1.4 (20.0 mg), with
$100 \%$ of $\mathrm{CH}_{2} \mathrm{Cl}_{2}$, obtaining seselin (1-2.3 mg). The remainder of FCD1.4 (102.4 mg) was chromatographed, with a polar gradient of $\mathrm{CH}_{2} \mathrm{Cl}_{2}: \mathrm{MeOH}$, generating 7 fractions (FCD1.4.1FCD1.4.7). FCD1.4.5 (66.5 mg) was chromatographed, with a polar gradient of $n$-hexane:acetone, obtaining braylin (2- $30.5 \mathrm{mg})$ and cedrelopsin (3- $6.4 \mathrm{mg})$ of fractions FCD1.4.5.3 and FCD1.4.5.7, respectively. FCD5 (8.9 g) was chromatographed, with a polar gradient of $n$-hexane:acetone, generating 9 fractions (FCD5.1 - FCD5.9). Fraction FCD5.7 $(54.7 \mathrm{mg})$ was chromatographed, with a polar gradient of $n$-hexane:acetone, obtaining cis-6-methoxykellactone (4- $34.6 \mathrm{mg}$ ) of fraction FCD5.7.4. Fraction FCD5.3 $(669.2 \mathrm{mg})$ was chromatographed, with a polar gradient of $n$-hexane:acetone, obtaining 6-methoxylomatin (5- 35.2 $\mathrm{mg}$ ) of fraction FCD5.3.6. The dichloromethane partition of wood bark (18.5 g) was fractionated by silica gel CC, with a polar gradient of $\mathrm{CH}_{2} \mathrm{Cl}_{2}: \mathrm{MeOH}$, obtaining 13 fractions (FCMD1-FCMD13). FCMD6 (1,1 g) was chromatographed, with a polar gradient of $n$-hexane:acetone, generating 8 fractions (FCMD6.1 - FCMD6.8). Fraction FCMD6.4 (104.2 mg) was chromatographed, with a polar gradient of $n$-hexane:acetone, generating 7 fractions (FCMD6.4.1FCMD6.4.7). FCMD6.4.5 (69.6 mg) was chromatographed, with a polar gradient of $n$-hexane:acetone, obtaining brayleyanin $(6-49.1 \mathrm{mg})$ of fraction FCMD6.4.5.3.

\section{Results and Discussion}

Six coumarins (Figure 1) were isolated and identified from the dichloromethane partitions of the stem and wood bark, which were identified as $\operatorname{Seselin}^{14}(\mathbf{1})$, Braylin $^{15}$ (2), Cedrelopsin ${ }^{16}(3)$, cis-6-methoxykellactone ${ }^{17}$ (4), 6-methoxylomatin ${ }^{18}(5)$, and Brayleyanin ${ }^{9}(6)$. These compounds were characterized by their spectral data of ${ }^{1} \mathrm{H}$ and ${ }^{13} \mathrm{C}-\mathrm{NMR}$ (1D and 2D) and GC/EIMS, involving comparison with data described in the literature (Supplementary Material).<smiles>C[C@H]1C=Cc2c(ccc3ccc(=O)oc23)O1</smiles><smiles>COc1cc2ccc(=O)oc2c2c1OC(C)(C)C=C2</smiles><smiles>COc1cc2ccc(=O)oc2c(CC=C(C)C)c1O</smiles><smiles></smiles><smiles>COc1cc2ccc(=O)oc2c2c1OC(C)(C)[C@H](O)[CH]2</smiles><smiles>COc1ccc2oc(=O)ccc2c1CC=C(C)C</smiles>

Figure 1. Prenylated coumarins isolated from Flindersia brayleyana 
For the identification of these coumarins, the NMR spectra were analyzed (Table 1) considering some characteristic parameters of the basic coumarin skeleton $\mathrm{C}_{3}(\mathrm{CH})_{6} \mathrm{O}_{2}=\mathrm{C}_{9} \mathrm{H}_{6} \mathrm{O}_{2}$ (six $s p^{2}$ aromatic carbons with $2 \mathrm{C}$ and $4 \mathrm{CH}$ and one $\mathrm{CH}=\mathrm{CH}-\mathrm{COO}$ unit): a) the presence of two doublets $(J$ around $9.0 \mathrm{~Hz}$, Table 1) represented by hydrogen $\delta_{\mathrm{H}}$ signals around $6.30(\mathrm{H}-3)$ and $7.60(\mathrm{H}-$ 4 , position receiving a mesomeric effect produced by conjugation with carbonyl group $\mathrm{C}-4$ and also receiving anisotropic effect generated by the aromatic ring) in the ${ }^{1} \mathrm{H}$ NMR spectra, confirmed by the homonuclear interactions of $\mathrm{H}-3$ and $\mathrm{H}-4$ observed in the $2 \mathrm{D}^{1} \mathrm{H}-{ }^{1} \mathrm{H}-\mathrm{COSY}$ spectra and correlated in the 2D HSQC $\left({ }^{1} J_{\mathrm{CH}}\right)$ spectra with the signals of atoms around $\delta_{\mathrm{C}} 112.0(\mathrm{CH}-3)$ and $143.0(\mathrm{CH}-$ 4 ), a position conjugated with the carbonyl carbon atom represented by the signal around $\delta_{C} 161$ in the ${ }^{13} \mathrm{C}$ NMR spectra (Table 1$) ; b$ ) the availability of four positions in the aromatic ring (CH-4 to $\mathrm{CH}-8)$ for the location of substituents; and c) when there is oxygenated substitution in the $\mathrm{C}-5$ carbon, $\mathrm{H}-4$ hydrogen can be found with values above $\delta_{\mathrm{H}} 8.00 .{ }^{19}$
Compound 1 appeared as a yellow solid. Its molecular formula was determined to be $\mathrm{C}_{14} \mathrm{H}_{12} \mathrm{O}_{3}$ by the EIMS ([M] ${ }^{+}$ at $m / z=228$ ). The ${ }^{13} \mathrm{C}$-APT NMR data revealed the presence of fourteen carbon atoms, including six quaternary carbons $\left(\mathrm{C}_{6}\right.$, including one carbonyl $\mathrm{O}=\mathrm{C}-\mathrm{O}$ and two oxygenated, $\mathrm{C}-7$ and C-9), six methines (including four olefinics), and two methyl groups. These data, which agree with the molecular formula $\mathrm{C}_{14} \mathrm{H}_{12} \mathrm{O}_{3}$ indicating 9 degrees of unsaturation, four corresponding to the aromatic ring, three to $\alpha, \beta$-unsaturated lactone including the $\mathrm{CH}=\mathrm{CHCOO}$ unit, and two to the pyran ring sustaining two methyl groups, combined with the information provided by $1 \mathrm{D}$ and $2 \mathrm{D}$ spectral analysis were used to postulate the structure of $\mathbf{1}$ as a typical angular pyranocoumarin. The ${ }^{1} \mathrm{H}$ NMR spectrum shows the hydrogen signals of $\mathrm{H}-3$ and $\mathrm{H}-4$ as doublets $(J=9.5 \mathrm{~Hz}$, cis-interaction spin-spin) at $\delta_{\mathrm{H}} 6.25$ and 7.62 , respectively, showing that C-5 is not replaced. The methyl groups $3 \mathrm{H}-4$ ' and $3 \mathrm{H}-5$ ' appear as a singlet signal at $\delta_{\mathrm{H}} 1.50(\mathrm{~s}, 6 \mathrm{H})$, correlated in the HSQC with the carbon signal at $\delta_{\mathrm{C}} 28.1$ (Table 1). Analyzing the $2 \mathrm{D}{ }^{1} \mathrm{H}-{ }^{1} \mathrm{H}-\mathrm{COSY}$ spectrum, the interactions between the hydrogens H-3/H-4 (J=9.4 Hz), H-5/H-6 ( J=8.4 Hz, ortho

Table 1. ${ }^{1} \mathrm{H}$ NMR $(500 \mathrm{MHz})$ and ${ }^{13} \mathrm{C}$ NMR $(125 \mathrm{MHz})$ NMR data of the prenylated coumarins 1-6. Chemical shifts $(\delta$, ppm) and coupling constants $(J$, in parenthesis) in $\mathrm{Hz}^{*}$

\begin{tabular}{|c|c|c|c|c|c|c|c|c|c|c|c|c|}
\hline & \multicolumn{2}{|c|}{$1\left(\mathrm{CDCl}_{3}\right)$} & \multicolumn{2}{|c|}{$2\left(\mathrm{CDCl}_{3}\right)$} & \multicolumn{2}{|c|}{$3\left(\mathrm{CDCl}_{3}\right)$} & \multicolumn{2}{|c|}{$\left.4\left(\mathrm{CD}_{3}\right)_{2} \mathrm{CO}+\mathrm{CD}_{3} \mathrm{OD}\right)$} & \multicolumn{2}{|c|}{$5\left(\mathrm{CDCl}_{3}\right)$} & \multicolumn{2}{|c|}{$6\left(\mathrm{CDCl}_{3}\right)$} \\
\hline & $\boldsymbol{\delta}_{\mathrm{c}}$ & $\delta_{\mathrm{H}}$ & $\boldsymbol{\delta}_{\mathrm{c}}$ & $\delta_{\mathrm{H}}$ & $\boldsymbol{\delta}_{\mathrm{C}}$ & $\delta_{\mathrm{H}}$ & $\boldsymbol{\delta}_{\mathrm{c}}$ & $\delta_{\mathrm{H}}$ & $\boldsymbol{\delta}_{\mathrm{C}}$ & $\delta_{\mathrm{H}}$ & $\boldsymbol{\delta}_{\mathrm{c}}$ & $\delta_{\mathrm{H}}$ \\
\hline 2 & 161.2 & - & 161.1 & - & 161.6 & - & 161.2 & - & 161.8 & - & 161.2 & - \\
\hline 3 & 112.6 & $6.25(\mathrm{~d}, 9.5)$ & 113.1 & $6.25(\mathrm{~d}, 9.4)$ & 113.1 & $6.29(\mathrm{~d}, 9.4)$ & 111.8 & $6.23(\mathrm{~d}, 9.4)$ & 112.9 & $6.24(\mathrm{~d}, 9.4)$ & 114.7 & $6.32(\mathrm{~d}, 9.4)$ \\
\hline 4 & 143.9 & $7.62(\mathrm{~d}, 9.5)$ & 143.8 & $7.59(\mathrm{~d}, 9.4)$ & 143.7 & $7.60(\mathrm{~d}, 9.4)$ & 145.0 & $7.89(\mathrm{~d}, 9.4)$ & 144.0 & $7.61(\mathrm{~d}, 9.4)$ & 143.4 & $7.61(\mathrm{~d}, 9.4)$ \\
\hline 5 & 127.8 & $7.23(\mathrm{~d}, 8.4)$ & 108.8 & $6.78(\mathrm{~s})$ & 105.1 & $6.74(\mathrm{~s})$ & 108.5 & $7.12(\mathrm{~s})$ & 106.3 & $6.75(\mathrm{~s})$ & 106.9 & $6.78(\mathrm{~s})$ \\
\hline 6 & 113.5 & $6.74(\mathrm{~d}, 8.4)$ & 145.6 & - & 143.7 & - & 146.2 & - & 146.2 & - & 150.0 & - \\
\hline 7 & 143.4 & - & 145.9 & - & 147.5 & - & 146.8 & - & 147.9 & - & 149.8 & - \\
\hline 8 & 109.3 & - & 110.2 & - & 114.3 & - & 112.3 & - & 108.7 & - & 124.9 & - \\
\hline 9 & 150.2 & - & 144.8 & - & 148.3 & - & 149.0 & - & 148.6 & - & 147.6 & - \\
\hline 10 & 112.8 & - & 111.4 & - & 111.2 & - & 111.1 & - & 111.1 & - & 114.4 & - \\
\hline 1 ' & 115.0 & $6.91(\mathrm{~d}, 10.1)$ & 115.2 & $6.87(\mathrm{~d}, 10.0)$ & 22.2 & $3.59(\mathrm{~d}, 7.2)$ & 65.1 & $4.95(\mathrm{~d}, 4.1)$ & 26.0 & $\begin{array}{c}3.15 \\
(\mathrm{dd}, 17.5,4.9) \\
2.96 \\
(\mathrm{dd}, 17.5,5.6)\end{array}$ & 23.0 & $3.58(\mathrm{~d}, 7.2)$ \\
\hline 2 ' & 130.8 & $5.75(\mathrm{~d}, 10.1)$ & 130.9 & $5.75(\mathrm{~d}, 10.0)$ & 120.7 & $5.31(\mathrm{t}, 7.2)$ & 73.9 & $3.80(\mathrm{~d}, 4.1)$ & 68.2 & $\begin{array}{c}3.91 \\
(\mathrm{dd}, 5.6,4.9)\end{array}$ & 121.5 & $\begin{array}{c}5.23 \\
(\mathrm{qt}, 7.2,1.4)\end{array}$ \\
\hline 3, & 77.2 & - & 78.1 & - & 133.2 & - & 78.8 & - & 78.4 & - & 132.5 & - \\
\hline 4, & 28.1 & $1.50(\mathrm{~s})$ & 28.3 & $1.52(\mathrm{~s})$ & 25.8 & $1.70(\mathrm{~s})$ & 24.7 & $1.47(\mathrm{~s})$ & 24.8 & $1.41(\mathrm{~s})$ & 25.7 & $1.68(\mathrm{~s})$ \\
\hline 5 , & 28.1 & $1.50(\mathrm{~s})$ & 28.3 & $1.52(\mathrm{~s})$ & 17.9 & $1.87(\mathrm{~s})$ & 22.8 & $1.42(\mathrm{~s})$ & 21.9 & $1.45(\mathrm{~s})$ & 18.0 & $1.85(\mathrm{~s})$ \\
\hline $1 "$ & - & - & - & - & - & - & - & - & - & - & 70.0 & $4.60(\mathrm{~d}, 7.2)$ \\
\hline $2 "$ & - & - & - & - & - & - & - & - & - & - & 120.3 & $\begin{array}{c}5.55 \\
(\mathrm{qt}, 7.3,1.3)\end{array}$ \\
\hline $3 "$ & - & - & - & - & - & - & - & - & - & - & 138.4 & - \\
\hline 4" & - & - & - & - & - & - & - & - & - & - & 25.8 & $1.79(\mathrm{~s})$ \\
\hline $5 "$ & - & - & - & - & - & - & - & - & - & - & 17.9 & $1.71(\mathrm{~s})$ \\
\hline $\mathrm{MeO}$ & - & - & 56.5 & $3.89(\mathrm{~s})$ & 56.3 & $3.95(\mathrm{~s})$ & 55.5 & $3.84(\mathrm{~s})$ & 56.35 & $3.88(\mathrm{~s})$ & 56.1 & $3.90(\mathrm{~s})$ \\
\hline
\end{tabular}

*Number of hydrogens bonded to carbon atoms deduced by ${ }^{13} \mathrm{C}$-APT-NMR spectra. Chemical shifts and coupling constants $(J)$ corresponding to hydrogen signals were obtained from $1 \mathrm{D}{ }^{1} \mathrm{H}$ NMR spectrum. $2 \mathrm{D}{ }^{1} \mathrm{H}-{ }^{1} \mathrm{H}-\mathrm{COSY},{ }^{1} \mathrm{H}-{ }^{1} \mathrm{H}-\mathrm{NOESY}$, HSQC $\left({ }^{1} J_{\mathrm{CH}}\right)$ and $\mathrm{HMBC}\left({ }^{2} J_{\mathrm{CH}}\right.$ and $\left.{ }^{3} J_{\mathrm{CH}}\right)$ spectra were also used in these structural elucidations 
relation), and $\mathrm{H}-1^{\prime} / \mathrm{H}-2^{\prime}$ ( $J=10.1 \mathrm{~Hz}$, cis-configuration) were confirmed (Table 1). The dimethylated pyranic ring was also deduced by observing in the 2D HMBC spectrum the correlations of $3 \mathrm{H}-4^{\prime} / 3 \mathrm{H}-5^{\prime}\left(\delta_{\mathrm{H}} 1.50, \mathrm{~s}\right)$ with both C-3' $\left(\delta_{\mathrm{C}}\right.$ $\left.77.2,{ }^{2} J_{\mathrm{CH}}\right)$ and $\mathrm{CH}-2{ }^{\prime}\left(\delta_{\mathrm{C}} 130.8,{ }^{3} J_{\mathrm{CH}}\right)$.

Thus, these NMR spectral data and the EIMS, revealing only four principal peaks at $m / z=228\left([\mathrm{M}]^{+}, 15.0 \%, 213\right.$ $(\mathrm{M}-15,100.0 \%)$, and $185(\mathrm{M}-15-28,22,5 \%)$ together with the proposed fragmentation mechanisms summarized in Scheme 1, enabled characterization of this prenylated coumarin as Seselin (1).

Compound $\mathbf{2}$ was isolated as yellowish crystals. The EIMS displayed a molecular ion peak at $m / z=258$, consistent with a molecular formula of $\mathrm{C}_{15} \mathrm{H}_{14} \mathrm{O}_{4}$ and compatible with the presence of one methoxyl group $(\mathrm{MeO})$ in comparison with compound 1 (Scheme 1). In fact, the $1 \mathrm{D}{ }^{1} \mathrm{H}$ and ${ }^{13} \mathrm{C}$-APT NMR spectral data in combination with the HMBC experiment indicated that $\mathbf{2}$ was very similar to Seselin (1), except for the presence of an additional methoxy group represented by signals at $\delta_{\mathrm{H}} 3.89 / \delta_{\mathrm{C}} 56.3$, confirmed by the 2D HMBC through heteronuclear correlation of the carbon signal at $\delta_{\mathrm{C}} 145.6(\mathrm{C}-6)$ with $3 \mathrm{H}\left(\delta_{\mathrm{H}} 3.89,{ }^{3} \mathrm{~J}_{\mathrm{CH}}\right)$ of the methoxyl group (MeOC-6). The location of a methoxyl group at C-6 was also confirmed by spatial dipolar interaction of $\mathrm{H}-5\left(\delta_{\mathrm{H}} 6.78, \mathrm{~s}\right)$ with both $\mathrm{H}-4\left(\delta_{\mathrm{H}} 7.59, \mathrm{~d}\right.$, $J=9.4 \mathrm{~Hz})$ and $\mathrm{H}_{3} \mathrm{CO}\left(\delta_{\mathrm{H}} 3.89, \mathrm{~s}\right)$ revealed by $2 \mathrm{D}^{1} \mathrm{H}-{ }^{1} \mathrm{H}-$ NOESY (Figure 2).

Compound $\mathbf{3}$ was isolated as a yellow oil and showed a molecular formula $\mathrm{C}_{15} \mathrm{H}_{16} \mathrm{O}_{4}$ deduced by the $[\mathrm{M}]^{+}$ion peak at $m / z=260$. Comparative analysis of the ${ }^{1} \mathrm{H}$ and ${ }^{13} \mathrm{C}$ NMR spectral data of $\mathbf{2}$ and $\mathbf{3}$ revealed a significant difference only in the region involving a pyran ring in $\mathbf{2}$ and the presence of an isoprene unit $\left(\mathrm{CH}_{2} \mathrm{CH}=\mathrm{CMe}_{2}, \delta_{\mathrm{H}} / \delta_{\mathrm{C}}: 3.59(\mathrm{~d}, J=7.2\right.$ $\mathrm{Hz}) / 22.2\left(\mathrm{CH}_{2}-1^{\prime}\right), 5.31 / 120.7$ (CH-2'), -/133.2 (C-3'), $1.70(\mathrm{~s}) / 25.8\left(\mathrm{CH}_{3}-4^{\prime}\right)$, and $1.87(\mathrm{~s}) / 17.9\left(\mathrm{CH}_{3}-5^{\prime}, \gamma\right.$ effect of the $\mathrm{CH}_{2}-1$ ') in $\mathbf{3}$ (Table 1). The methoxyl group linked to $\mathrm{C}-6$ was confirmed by the $\mathrm{HMBC}$ correlation between $\delta_{\mathrm{H}}$ $3.89(\mathrm{OMe})$ and $\delta_{\mathrm{C}} 143.7\left(\mathrm{C}-6,{ }^{3} J_{\mathrm{CH}}\right)$. The HMBC spectrum of 3 also showed heteronuclear correlations of two singlet signals $3 \mathrm{H}-4$ ' $\left(\delta_{\mathrm{H}} 1.70\right)$ and $3 \mathrm{H}-5,\left(\delta_{\mathrm{H}} 1.87\right)$ with both CH-2' $\left(\delta_{\mathrm{C}} 120.7,{ }^{3} J_{\mathrm{CH}}\right)$ and C-3' $\left(\delta_{\mathrm{C}} 133.2,{ }^{2} J_{\mathrm{CH}}\right), 3 \mathrm{H}-4{ }^{\prime}\left(\delta_{\mathrm{H}}\right.$ $1.70)$ with $\mathrm{CH}_{3}-5,\left(\delta_{\mathrm{C}} 17.9,{ }^{3} \mathrm{~J}_{\mathrm{CH}}\right)$, and $3 \mathrm{H}-5$ ' $\left(\delta_{\mathrm{H}} 1.87\right)$ with $\mathrm{CH}_{3}-4$ ' $\left(\delta_{\mathrm{C}} 25.8,{ }^{3} J_{\mathrm{CH}}\right)$ confirming the presence of the two methyl groups $3 \mathrm{H}-4$ ' and $3 \mathrm{H}-5$ ' bonded to the same carbon atom C-3' (3'-CMe ${ }_{2}$ ). As observed in 2, the location of the

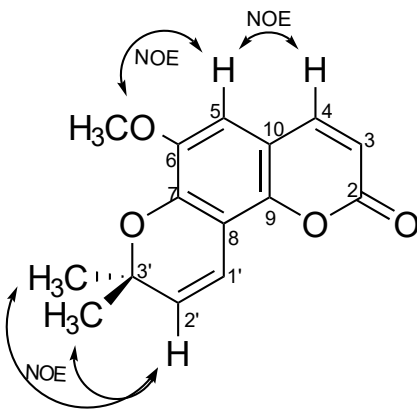

Figure 2. Correlation $2 \mathrm{D}{ }^{1} \mathrm{H}-{ }^{1} \mathrm{H}-\mathrm{NOESY}$ of compound 2

methoxyl group in C-6 was also confirmed by spatial dipolar interaction of $\mathrm{H}-5\left(\delta_{\mathrm{H}} 6.74, \mathrm{~s}\right)$ with both $\mathrm{H}-4\left(\delta_{\mathrm{H}} 7.60, \mathrm{~d}\right.$, $J=9.4 \mathrm{~Hz})$ and $\mathrm{H}_{3} \mathrm{CO}\left(\delta_{\mathrm{H}} 3.89, \mathrm{~s}\right)$, revealed by $2 \mathrm{D}{ }^{1} \mathrm{H}-{ }^{1} \mathrm{H}-$ NOESY (Figure 3). The presence of the isoprenyl unit in the ortho position of the hydroxyl group can also can be used to justify the presence of the peak at $m / z=204$ ([M] ${ }^{+}$ $-\mathrm{H}_{2} \mathrm{C}=\mathrm{CMe}_{2}$ ) of the EIMS spectrum of $\mathbf{3}$ and formed by a fragmentation reaction below that postulated (Scheme 2).

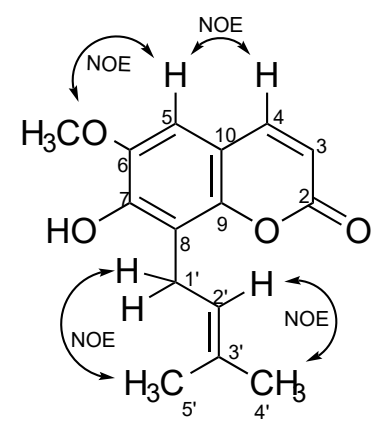

Figure 3. Correlation $2 \mathrm{D}{ }^{1} \mathrm{H}-{ }^{1} \mathrm{H}-\mathrm{NOESY}$ of compound 3

Thus, all these data confirmed the presence of the isoprenyl unit in $\mathbf{3}$, enabling its identification as Cedrelopsin (3).

The molecular formula $\mathrm{C}_{15} \mathrm{H}_{16} \mathrm{O}_{6}$ of $\mathbf{4}$ (yellow solid) was established by EIMS $\left.(m / z=292,[\mathrm{M}]]^{+}\right)$. The ${ }^{1} \mathrm{H}$ and ${ }^{13} \mathrm{C}$ NMR spectral data (Table 1) of $\mathbf{4}$ were very similar to those of $\mathbf{2}$, differing only in the $s p^{2} \mathrm{CH}-1$ ' and $\mathrm{CH}-2$ ' carbons of the pyran ring of $\mathbf{2}$, now in $\mathbf{4}$ as methine carbons $s p^{3}$ sustaining hydroxyl groups: $\delta_{\mathrm{H}} / \delta_{\mathrm{C}} 4.91(\mathrm{~d}, J=4.0 \mathrm{~Hz}) / 65.1\left(\mathrm{HOCH}-1^{\prime}, \gamma\right.$ effect of the methyl groups $\mathrm{CH}_{3}-4^{\prime}$ and $\mathrm{CH}_{3}-5$ ') and 3.80 (d, $J=4.0 \mathrm{~Hz}) / 73.9\left(\mathrm{HOCH}-2^{\prime}\right)$. The value of $J=4.1 \mathrm{~Hz}$ observed

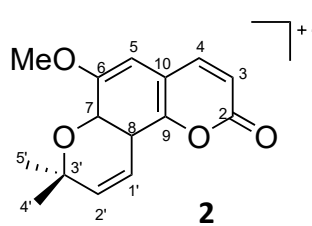

$\mathrm{m} / \mathrm{h}=258\left([\mathrm{M}]^{+}, 37.2 \%\right) \longrightarrow$

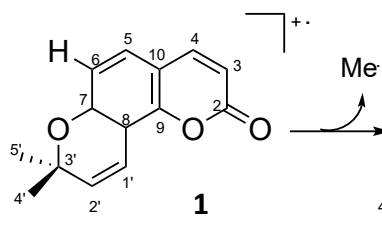

$1 \mathrm{~m} / \mathrm{z}=228\left([\mathrm{M}]^{+}\right.$, , 15.0\%) $2 \mathrm{~m} / \mathrm{z}=228\left([\mathrm{M}]^{+}\right.$, , 30.2\%)<smiles></smiles>

Me $\quad 1 \mathrm{~m} / \mathrm{z}=213(100.0 \%)$ $\stackrel{2}{\longrightarrow} 2 \mathrm{~m} / \mathrm{z}=243(100.0 \%)$

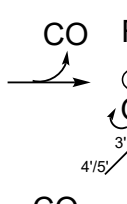

$\mathrm{CO}$

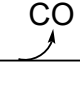

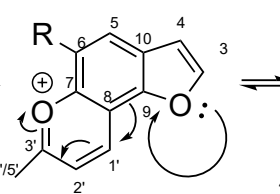

$1 \mathrm{~m} / z=185(22.5 \%)$

$2 \mathrm{~m} / \mathrm{z}=215(9.3 \%)$

Scheme 1. Proposed fragmentation mechanisms of $\mathbf{1}$ and $\mathbf{2}$ (only peaks classified as principals) 

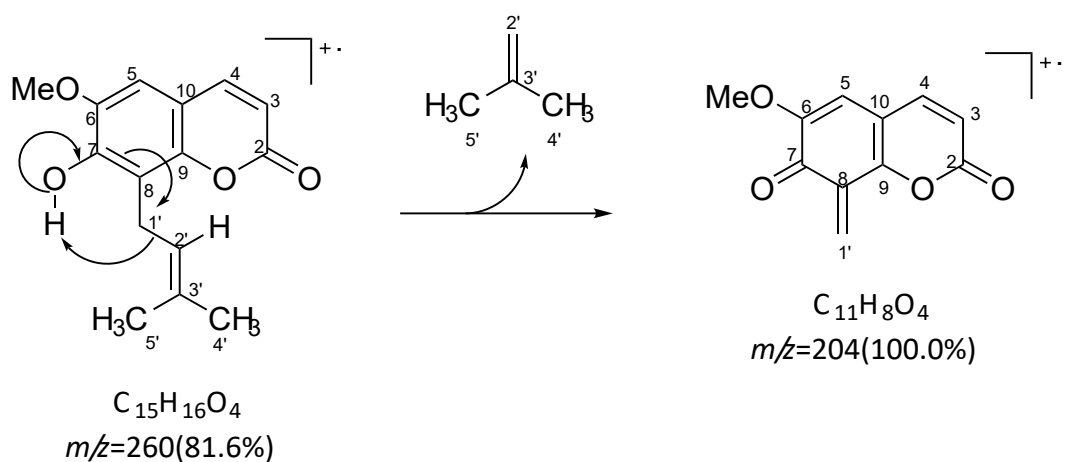

Scheme 2. Proposed fragmentation mechanisms of $\mathbf{3}$ (only peaks classified as principals)

in the hydrogen signals of H-1' and H-2' suggest an axial/ equatorial or equatorial/equatorial interaction.

The presence of the peak at $m / z=220$ (peak basic) in the EIMS spectrum of $\mathbf{4}$, formed by a fragmentation reaction below that postulated (Scheme 3), supported these conclusions.

Structure 4a (Figure 4) reveals results obtained by 2D ${ }^{1} \mathrm{H}-{ }^{1} \mathrm{H}-\mathrm{NOESY}$ spectrum of 4 , including a postulated relative configuration.

Compound $5(m / z=276)$ appeared as a dark yellow solid. The EIMS displayed a molecular ion peak at $m / z=276$ $\left([\mathrm{M}]^{+}\right)$, consistent with a molecular formula of $\mathrm{C}_{15} \mathrm{H}_{16} \mathrm{O}_{5}$. Comparative analysis of the ${ }^{1} \mathrm{H}$ and ${ }^{13} \mathrm{C}$ NMR (1D and 2D) spectral data of $\mathbf{5}$ and $\mathbf{4}$ revealed results that were similar, except for the absence of signals corresponding $\mathrm{HOCH}-1$ ' $\left(\delta_{\mathrm{H}} 4.95\left(\mathrm{~d}, J=4.1 \mathrm{~Hz}, \mathrm{H}-1^{\prime}\right) / \delta_{\mathrm{C}} 65.1, \mathrm{CH}-1\right.$ ') $)$ in the spectra of 4 , and the presence of signals attributed to methylene group $\mathrm{H}_{2} \mathrm{C}-1$ ' $\left[\delta_{\mathrm{H}} 3.15(\mathrm{dd}, J=17.5,4.9 \mathrm{~Hz}, \mathrm{H}-1\right.$ ' ' a) and 2.96 (dd, $J=17.5,5.6 \mathrm{~Hz}, \mathrm{H}-1$ ' $\left.\mathrm{b}) / \delta_{\mathrm{C}} 26.0, \mathrm{CH}_{2}-1^{\prime}\right]$ in the spectra of 5. The signal of the H-2' in the ${ }^{1} \mathrm{H}$ NMR spectrum of
5 was, as anticipated, observed as a double-doublet at $\delta_{\mathrm{H}}$ $3.91(\mathrm{dd}, J=4.9,5.6 \mathrm{~Hz}) / \delta_{\mathrm{C}} 68.2$ revealing vicinal spin-spin couplings with the two hydrogen atoms $2 \mathrm{H}-1$ ' $\left[\delta_{\mathrm{H}} 3.15(\mathrm{dd}\right.$, $J=17.5,4.9 \mathrm{~Hz}, \mathrm{H}-1$ 'a) and 2.96 (dd, $J=17.5,5.6 \mathrm{~Hz}, \mathrm{H}-1$ 'b) $/ \delta_{\mathrm{C}} 26.0$. The values of the vicinal coupling constants $J=4.9$ $\mathrm{Hz}$ and $J=5.6 \mathrm{~Hz}$ were used to postulate the axial position (Figure 5) for a hydroxyl group on carbon $\mathrm{CH}-2$ ' (equatorial position for hydrogen $\mathrm{H}-2$ '), because when involving an equatorial-axial interaction the $J$ ranges from $0-5 \mathrm{~Hz}$ and axial-axial from 6-14 $\mathrm{Hz}^{20}$

The presence of the peak at $\mathrm{m} / \mathrm{z}=206$ (peak basic) in the EIMS spectrum of $\mathbf{5}$, formed by a fragmentation reaction below that postulated (Scheme 4), supported these conclusions.

Figure 5 presents important spatial correlations obtained by $2 \mathrm{D}{ }^{1} \mathrm{H}-{ }^{1} \mathrm{H}-\mathrm{NOESY}$ spectrum of $\mathbf{5}$, prenylated coumarin isolated from Flindersia brayleyana and known as 6-methoxylomatin (5).

Compound $6(\mathrm{~m} / \mathrm{z}=328)$ was isolated as a yellow solid. Comparison of the EIMS of this compound $\left(6, m / z 328[\mathrm{M}]^{+}\right.$,

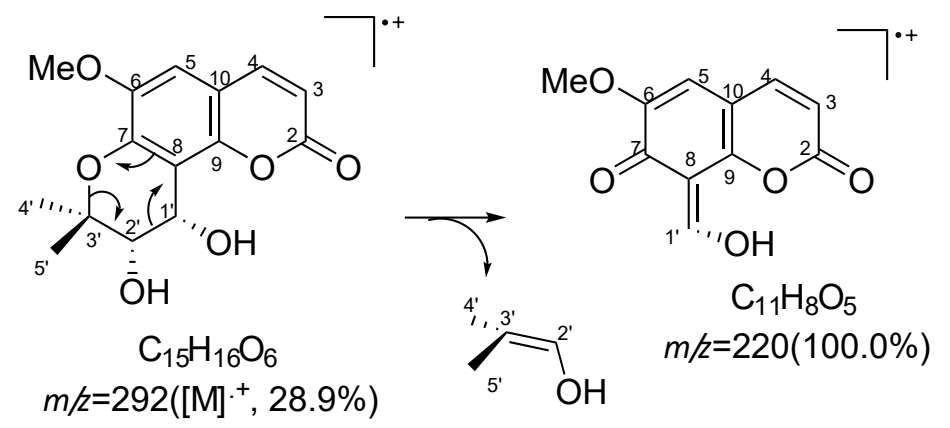

Scheme 3. Proposed fragmentation mechanisms of $\mathbf{4}$ (only peaks classified as principals)

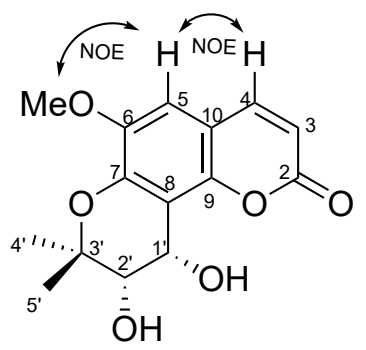

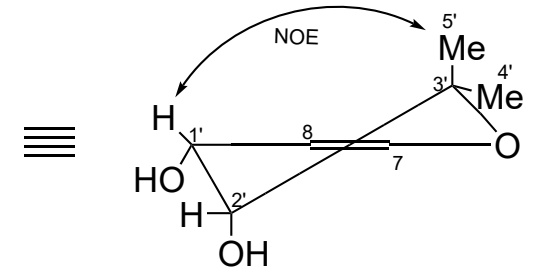

$4 a$

Figure 4. Correlation $2 \mathrm{D}{ }^{1} \mathrm{H}-{ }^{1} \mathrm{H}-\mathrm{NOESY}$ of compound 4 

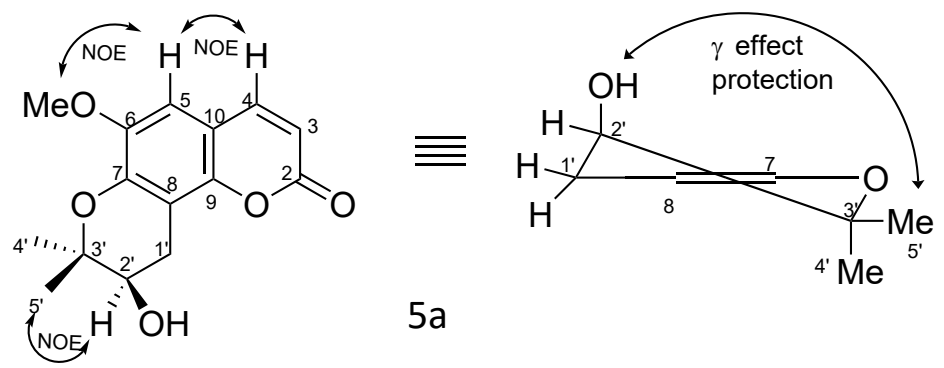

$5 a$

Figure 5. Correlation $2 \mathrm{D}{ }^{1} \mathrm{H}-{ }^{1} \mathrm{H}-\mathrm{NOESY}$ of compound $\mathbf{5}$

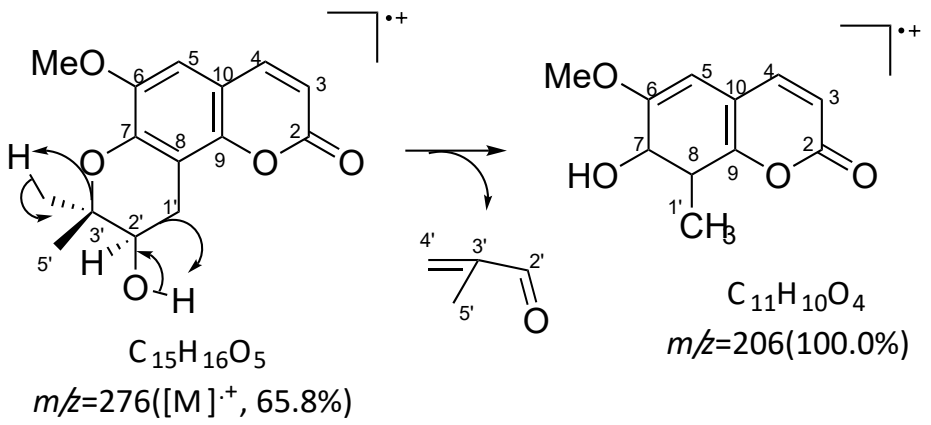

Scheme 4. Proposed fragmentation mechanisms of 5 (only peaks classified as principals)

relative abundance $100.0 \%$, molecular formula $\mathrm{C}_{20} \mathrm{H}_{24} \mathrm{O}_{4}$, Scheme 5) with compound $3\left(\mathrm{~m} / z 260[\mathrm{M}]^{+}\right.$, relative abundance $81.6 \%$, molecular formula $\mathrm{C}_{15} \mathrm{H}_{16} \mathrm{O}_{4}$ ) revealed a difference of $\mathrm{C}_{5} \mathrm{H}_{8}$ compatible with one additional isoprenyl unit $\left(\mathrm{Me}_{2} \mathrm{C}=\mathrm{CH}-\mathrm{CH}_{2}\right.$ - substituting one hydrogen atom in the molecule of 3 ) bonded to an oxygen atom, justifying the significant difference in the chemical shifts of the ${ }^{1} \mathrm{H} /{ }^{13} \mathrm{C}$ $\left(\delta_{\mathrm{H}} 4.60(\mathrm{~d}, J=7.2 \mathrm{~Hz}) / \delta_{\mathrm{C}} 70.0\right)$ in 6.

In fact, in the ${ }^{1} \mathrm{H}$ NMR spectrum of $\mathbf{6}$, four singlet signals were observed corresponding to four methyl groups, with values of $\delta_{\mathrm{H}} 1.85,1.79,1.71$, and 1.68 , chemical shifts suggesting a bond in four $\mathrm{sp}^{2}$ carbon atoms, also in accordance with the presence of two isoprenyl units.

Comparative analysis of the ${ }^{1} \mathrm{H}$ and ${ }^{13} \mathrm{C}$ NMR spectral data of $\mathbf{3}$ and $\mathbf{6}$ revealed significant differences only in the region involving the substituents sustained by aromatic carbon atoms C-6, C-7, and C-8, compatible with the etherification of the hydroxyl group bonded to carbon atom 7 with one isoprenyl unit (Table 2 and Scheme 5).

Two doublets of each compound are attributed as the characteristic signals of the hydrogens $\mathrm{H}-3\left[\mathbf{3} / \mathbf{6}: \delta_{\mathrm{H}} 6.29\right.$ $(\mathrm{d}, 9.4 \mathrm{~Hz}) / 6.32(\mathrm{~d}, 9.4 \mathrm{~Hz})]$ and $\mathrm{H}-4$ [3/6: $\delta_{\mathrm{H}} 7.60(\mathrm{~d}, 9.4$ $\mathrm{Hz}) / 7.61(\mathrm{~d}, 9.4 \mathrm{~Hz})]$, correlated in the 2D HSQC with carbon signals of the $\mathrm{CH}-3\left(\mathbf{3 / 6}: \delta_{\mathrm{C}} 113.1 / 114.7\right)$ and CH-4 (3/6: $\delta_{\mathrm{C}}$ 143.7/143.4). The signals with a value of $\delta_{\mathrm{C}} 23.0$ and $\delta_{\mathrm{H}} 3.58(\mathrm{~d}, 7.2 \mathrm{~Hz})$ were assigned to $\mathrm{CH} 2-1$ '. The signals at $\delta_{\mathrm{C}} 70.0 / \delta_{\mathrm{H}} 4.60(\mathrm{~d}, 7.2 \mathrm{~Hz})$ were attributed to methylene oxygenated $\mathrm{CH} 2-1$ " $\left(1\right.$ " $\left.-\mathrm{CH}_{2}-\mathrm{O}\right)$ bonded to C-7 carbon. This location was unequivocally confirmed by the heteronuclear spin-spin interaction between carbon C-7 $\left(\delta_{\mathrm{C}} 149.8\right)$ and hydrogens $2 \mathrm{H}-1$ ' $\left[\delta_{\mathrm{H}} 3.58(\mathrm{~d}, J=7.2 \mathrm{~Hz})\right.$, $\left.{ }^{3} J_{\mathrm{CH}}\right], 2 \mathrm{H}-1$ " $\left[\delta_{\mathrm{H}} 4.60(\mathrm{~d}, J=7.2 \mathrm{~Hz}),{ }^{3} J_{\mathrm{CH}}\right)$, and H-5 $\left(\delta_{\mathrm{H}} 6.78\right.$ (s), $\left.{ }^{3} J_{\mathrm{CH}}\right]$ revealed by cross-peaks observed in the HMBC spectrum of $\mathbf{6}$ (Table 2). The analog result was observed in the HMBC spectrum of $\mathbf{3}$ revealing interactions only of C-7 $\left(\delta_{\mathrm{C}} 147.5\right)$ with $2 \mathrm{H}-1$ ' $\left[\delta_{\mathrm{H}} 3.59(\mathrm{~d}, J=7.2 \mathrm{~Hz}),{ }^{3} J_{\mathrm{CH}}\right.$ and $\mathrm{H}-5$ $\left(\delta_{\mathrm{H}} 6.74(\mathrm{~s}),{ }^{3} J_{\mathrm{CH}}\right]$ (Table 2).

For further clarification, Table 1 shows only the values of the chemical shifts of ${ }^{1} \mathrm{H}(\mathrm{H}$ and coupling constants in $\mathrm{Hz})$ and ${ }^{13} \mathrm{C}\left(\delta_{\mathrm{C}}\right.$, number of hydrogens bonded to carbon atoms deduced by ${ }^{13} \mathrm{C}$-APT) of $\mathbf{1}$ to $\mathbf{6}$. The results of the extensive application of 1D and 2D NMR spectral techniques were also used to confirm the structure and establish the ${ }^{1} \mathrm{H}$ and ${ }^{13} \mathrm{C}$ resonance assignments of 1-6 (3 and $\mathbf{6}$ in Table 2 to exemplify, with the additional results of heteronuclear longrange couplings also used to prepare Table 1).

\section{Conclusions}

Six prenylated coumarins, 1-6 were isolated from Flindersia brayleyana, confirming the major presence of this class of secondary metabolites in this species. These secondary metabolites have been previously identified from the wood bark of the same species, in addition, these coumarins are present in several genera of the Rutaceae family.

The structures of these prenylated coumarins (1-6) were elucidated using 1D and 2D ${ }^{1} \mathrm{H} \mathrm{NMR}$ and ${ }^{13} \mathrm{C}$ NMR spectral data, based on characteristic peaks and correlations observed in the experiments, and also, low-resolution mass spectra, confirming the proposed structure to from the mass obtained.

It was possible to notice that $\mathbf{1}$ and $\mathbf{2}$ have similarities between their structures, being different only by a methoxy 


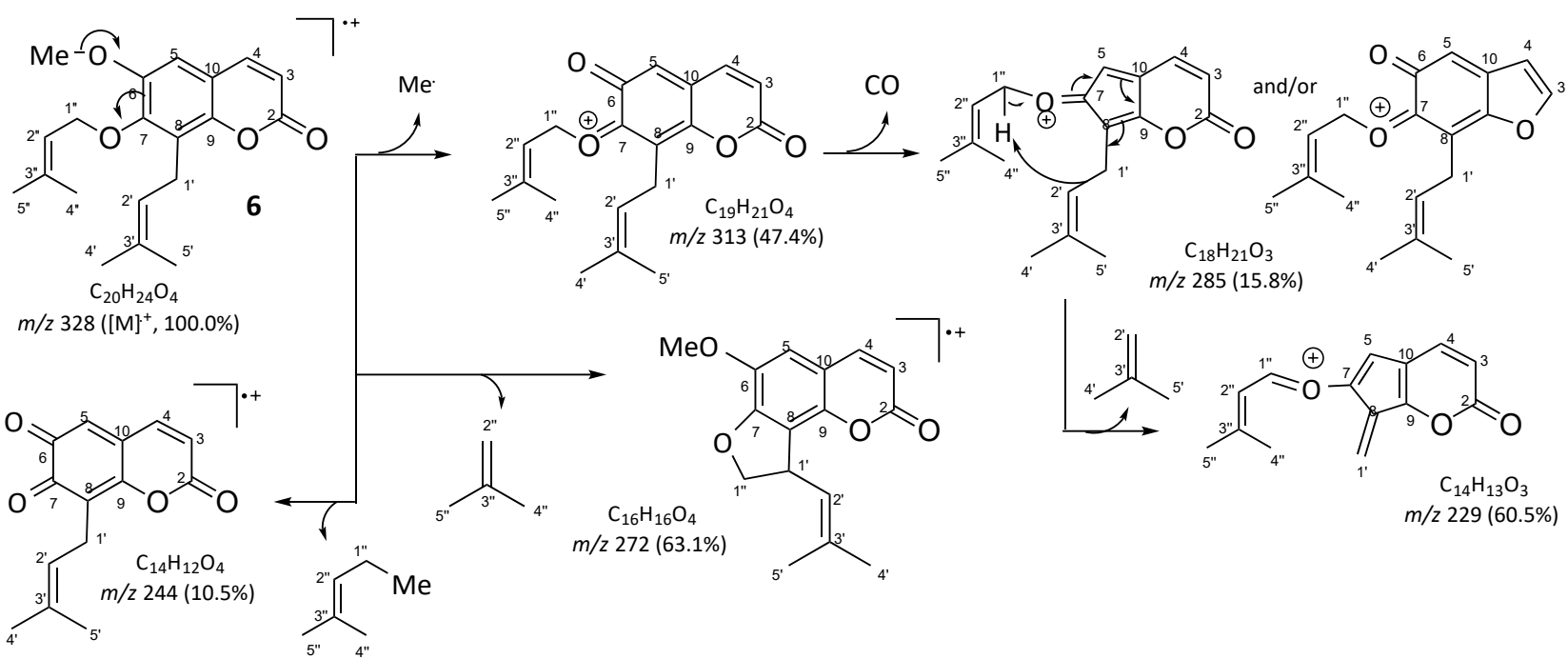

Scheme 5. Proposed fragmentation mechanisms of 6 (only peaks classified as principals)

Table 2. ${ }^{1} \mathrm{H}$ NMR (500 MHz) and ${ }^{13} \mathrm{C}$ NMR (125 MHz) NMR data of the prenylated coumarins 3 and $\mathbf{6}$, including direct $\left({ }^{1} J_{\mathrm{CH}}\right)$, observed in the HSQC, and long-range couplings of hydrogen and carbon atoms in the $\mathrm{HMBC}\left({ }^{2} J_{\mathrm{CH}}\right.$ and $\left.{ }^{3} J_{\mathrm{CH}}\right)$ spectra, in $\mathrm{CDCl}_{3}$ as solvent. Chemical shifts $(\delta$, ppm) and coupling constants $(J, \mathrm{~Hz}$, in parenthesis)*

\begin{tabular}{|c|c|c|c|c|c|c|c|c|}
\hline & \multicolumn{4}{|c|}{$3\left(\mathrm{CDCl}_{3}\right)$} & \multicolumn{4}{|c|}{$6\left(\mathrm{CDCl}_{3}\right)$} \\
\hline & \multicolumn{2}{|c|}{ HSQC } & \multicolumn{2}{|c|}{ НMBC } & \multicolumn{2}{|r|}{ HSQC } & \multicolumn{2}{|c|}{ HMBC } \\
\hline & $\delta_{\mathrm{C}}$ & $\delta_{\mathbf{H}}$ & ${ }^{2} J_{\mathrm{CH}}$ & ${ }^{3} J_{\mathrm{CH}}$ & $\delta_{\mathrm{C}}$ & $\delta_{\mathrm{H}}$ & ${ }^{2} J_{\mathrm{CH}}$ & ${ }^{3} J_{\mathrm{CH}}$ \\
\hline 2 & 161.6 & - & $\mathrm{H}-3$ & $\mathrm{H}-4$ & 161.2 & - & $\mathrm{H}-3$ & $\mathrm{H}-4$ \\
\hline 3 & 113.1 & $6.29(\mathrm{~d}, 9.4)$ & $\mathrm{H}-4$ & & 114.7 & $6.32(\mathrm{~d}, 9.4)$ & & \\
\hline 4 & 143.7 & $7.60(\mathrm{~d}, 9.4)$ & $\mathrm{H}-3$ & & 143.4 & $7.61(\mathrm{~d}, 9.4)$ & H-5 & \\
\hline 5 & 105.1 & $6.74(\mathrm{~s})$ & & $\mathrm{H}-4$ & 106.9 & $6.78(\mathrm{~s})$ & & $\mathrm{H}-4$ \\
\hline 6 & 143.7 & - & H-5 & $\mathrm{MeO}-6$ & 150.0 & - & H-5 & $\mathrm{MeO}-6$ \\
\hline 7 & 147.5 & - & & H-5; 2H-1' & 149.8 & - & & H-5; 2H-1'; 2H-1" \\
\hline 8 & 114.3 & - & $2 \mathrm{H}-1^{\prime}$ & H-2' & 124.9 & - & $2 \mathrm{H}-1^{\prime}$ & \\
\hline 9 & 148.3 & - & & $\mathrm{H}-4 ; 2 \mathrm{H}-1$ & 147.6 & - & & H-4; H-5; 2H-1' \\
\hline 10 & 111.2 & - & H-5 & $\mathrm{H}-3$ & 114.4 & - & $\mathrm{H}-4$ & $\mathrm{H}-3$ \\
\hline $1^{\prime}$ & 22.2 & $3.59(\mathrm{~d}, 7.2)$ & $\mathrm{H}-2^{\prime}$ & & 23.0 & $3.58(\mathrm{~d}, 7.2)$ & & \\
\hline $2^{\prime}$ & 120.7 & $5.31(\mathrm{t}, 7.2)$ & $2 \mathrm{H}-1^{\prime}$ & $3 \mathrm{H}^{-} 4^{\prime} ; 3 \mathrm{H}-5^{\prime}$ & 121.5 & $5.23(\mathrm{qt}, 7.2,1.4)$ & $2 \mathrm{H}-1$ & $3 \mathrm{H}-4^{\prime} ; 3 \mathrm{H}-5^{\prime}$ \\
\hline $3^{\prime}$ & 133.2 & - & $3 \mathrm{H}^{\prime} 4^{\prime} ; 3 \mathrm{H}-5^{\prime}$ & $2 \mathrm{H}-1^{\prime}$ & 132.5 & - & $3 \mathrm{H}^{-4} ; 3 \mathrm{H}-5{ }^{\prime}$ & $2 \mathrm{H}-1$ \\
\hline $4^{\prime}$ & 25.8 & $1.70(\mathrm{~s})$ & & H-2'; 3H-5' & 25.7 & $1.68(\mathrm{~s})$ & & H-2'; 3H-5' \\
\hline 5 & 17.9 & $1.87(\mathrm{~s})$ & & H-2'; 3H-4' & 18.0 & $1.85(\mathrm{~s})$ & & H-2'; 3H-4' \\
\hline $1 "$ & - & - & - & - & 70.0 & $4.60(\mathrm{~d}, 7.2)$ & & \\
\hline $2 "$ & - & - & - & - & 120.3 & $5.55(\mathrm{qt}, 7.2,1.3)$ & $2 \mathrm{H}-1 "$ & $3 \mathrm{H}-4 " ; 3 \mathrm{H}-5 "$ \\
\hline $3 "$ & - & - & - & - & 138.4 & - & $3 \mathrm{H}-4 " ; 3 \mathrm{H}-5 "$ & $2 \mathrm{H}-1 "$ \\
\hline $4 "$ & - & - & - & - & 25.8 & $1.79(\mathrm{~s})$ & & H-2”; 3H-5" \\
\hline $5 "$ & - & - & - & - & 17.9 & $1.71(\mathrm{~s})$ & & H-2"; 3H-4" \\
\hline $\mathrm{MeO}$ & 56.3 & $3.95(\mathrm{~s})$ & & & 56.1 & $3.90(\mathrm{~s})$ & & \\
\hline
\end{tabular}

*Number of hydrogens bonded to carbon atoms deduced by $-{ }^{13} \mathrm{C}$-APT-NMR spectra. Chemical shifts and coupling constants $(J)$ corresponding to hydrogen signals were obtained from 1D ${ }^{1} \mathrm{H}$ NMR spectrum. 2D ${ }^{1} \mathrm{H}-{ }^{1} \mathrm{H}-\mathrm{COSY}$ and ${ }^{1} \mathrm{H}-{ }^{-1} \mathrm{H}-\mathrm{NOESY}$ spectra were also used in these structural elucidations 
group in C-6; $\mathbf{3}$ and $\mathbf{6}$ are similar to have isoprenyl groups and, therefore, do not form the pyranic ring; and $\mathbf{4}$ and $\mathbf{5}$ are similar due to the presence of hydroxyl groups in the pyranic ring.

\section{Acknowledgements}

The authors are grateful to the Fundação de Amparo à Pesquisa do Estado do Rio de Janeiro (FAPERJ), Conselho Nacional de Desenvolvimento Científico e Tecnológico (CNPq), and Coordenação de Aperfeiçoamento de Pessoal de Nível Superior (CAPES) for grants, graduate scholarships, and a research fellowship.

\section{References}

1. Viegas Jr, C.; Bolzani, V. S.; Barreiro, E. J.; Os produtos naturais e a química medicinal moderna. Química Nova 2006, 29, 326. [CrossRef]

2. Pinto, A. C.; Silva, D. H. S.; Bolzani, V. D. S.; Lopes, N. P.; Epifanio, R. D. A.; Produtos naturais: atualidade, desafios e perspectivas. Química Nova 2002, 25, 45. [CrossRef]

3. Pirani, J. R.; Flora da Reserva Ducke, Amazonas, Brasil: Rutaceae. Rodriguésia 2005, 56, 189. [CrossRef]

4. Groppo, M.; Pirani, J. R.; Salatino, M. L.; Blanco, S. R.; Kallunki, J. A.; Phylogeny of Rutaceae based on two non coding regions from cpDNA. American Journal of Botany 2008, 95, 985. [CrossRef] [PubMed]

5. Afonso, L. F; Dissertação de Mestrado, Universidade de São Paulo, 2018. [CrossRef]

6. Robertson, L. P.; Hall, C. R.; Forster, P. I.; Carroll, A. R.; Alkaloid diversity in the Folhas of Australian Flindersia (Rutaceae) Espécies driven by adaptation to aridity. Phytochemistry 2018, 152, 71. [CrossRef] [PubMed]

7. Hartley, T. G.; A revision of the genus Flindersia (Rutaceae). Journal of the Arnold Arboretum 1969, 50, 481. [Link]

8. Brophy, J. J.; Goldsack, R. J.; Forster, P. I.; The leaf oils of the Australian Espécies of Flindersia (Rutaceae). Journal of Essential Oil Research 2005, 17, 388. [CrossRef]

9. Moreira, A. S. N.; Mathias, L.; Braz-Filho, R.; Schripsema, J.; Vieira, I.; Two new diprenylated coumarins from Flindersia brayleyana. Natural Product Letters, 2002, 16, 291. [CrossRef]
10. Montagner, C.; Dissertação de Mestrado, Universidade Federal de Santa Catarina, 2007. [Link]

11. Bernabé-Antonio, A.; Álvarez-Berber, L. P.; Cruz-Sosa, F.; Biological Importance of Phytochemicals from Calophyllum brasiliense Cambess. Annual Research \& Review in Biology, 2014, 4, 1502. [CrossRef]

12. Brenzan, M. A.; Santos, A. O.; Nakamura, C. V.; Filho, B. P.; Ueda-Nakamura T., Young, M. C.; Correa, A. G.; Junior, J. A.; Morgado-Diaz, J. A.; Cortez, D. A.; Effects of (-) mammea A/ $\mathrm{BB}$ isolated from Calophyllumbrasiliense leaves and derivatives on mitochondrial membrane of Leishmania amazonenses. Phytomedicine: international journal of phytotherapy and phytopharmacology 2012, 19, 223. [CrossRef]

13. Sarker, S. D.; Nahar, L.; Progress in the chemistry of naturally occurring coumarins. Progress in the Chemistry of Organic Natural Products 2017, 106, 241. [CrossRef]

14. Mukandiwa, L.; Ahmed, A.; Eloff, J. N.; Naidoo, V.; Isolation of seselin from Clausena anisata (Rutaceae) leaves and its effects on the feeding and development of Lucilia cuprina larvae may explain its use in ethnoveterinary medicine. Journal of ethnopharmacology 2013, 150, 886. [CrossRef]

15. Sales, E. M.; Barros, T. F.; Velozo, E. D. S.; Biotransformation of coumarins by Saccharomyces cerevisiae. World Journal of Pharmacy and Pharmaceutical Sciences 2014, 3, 209. [Link]

16. Mahibalan, S.; Rao, P. C.; Khan, R.; Basha, A.; Siddareddy, R.; Masubuti, H; Fujimoto, Y.; Begum, A. S.; Cytotoxic constituents of Oldenlandia umbellata and isolation of a new symmetrical coumarin dimer. Medicinal Chemistry Research 2016, 25, 466. [CrossRef]

17. Toro, M. J.; Müller, A. H.; Arruda, M. S.; Arruda, A. C.; Alkaloids and coumarins from Ticorea longiflora. Phytochemistry 1997 , 45, 851. [CrossRef]

18. Page, P. C. B.; Appleby, L. F.; Day, D.; Chan, Y.; Buckley, B. R.; Allin, S. M.; McKenzie, M. J.; Highly enantioselective total synthesis of (-)-(3'S)-lomatin and (+)-(3'S, 4'R)-transkhellactone. Organic Letters 2009, 11, 1991. [CrossRef]

19. Perel'son, M. E.; Sheinker, Y. N.; Syrova, G. P.; Turchin, K. F.; NMR spectra of natural coumarin derivatives. Chemistry of Natural Compounds 1970, 6, 5. [CrossRef]

20. Silverstein, R. M.; Webster, F. X.; Kiemle, D. J.; Spectrometric identification of organic compounds, 7a. ed., LTC Editora: Rio de Janeiro, 2006. 